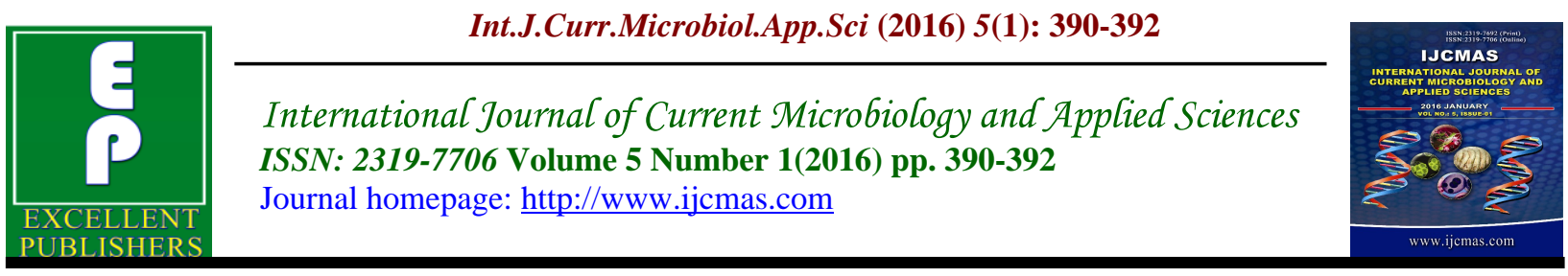

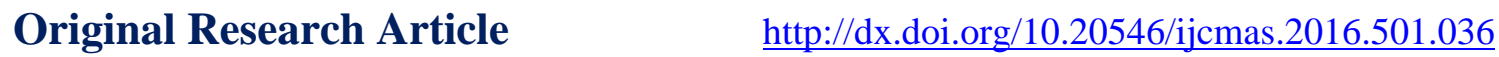

\section{Studies on behavior of land slug Semperula maculata during aestivation}

\author{
D.L. Bharamal* \\ Department of Zoology, S.P.K.Mahavidyalaya, Sawantwadi Dist. \\ Sindhudurg (MS) 416510, India \\ *Corresponding author
}

\section{A B S T R A C T}

\section{Keywords}

Semperula

maculate, Aestivation,

\section{Article Info}

Accepted:

16 December 2015

Available Online:

10 January 2016
The study aims to know behavior of the pest slug Semperula maculata was studied during the aestivation and refeeding. The behavioral observations were mainly noted with respect to movements (crowing and burrowing), courtship, feeding preference towards the food, water and soil. These observations were made daily at 6.00 a.m., 12.00 noon and 6.00 p.m. Besides these observations because of slug's nocturnal habitat these observations were observed in the night at 10.00 p.m. and 1.00 a.m. The behavior was particularly observed at rest, during sprinkling water and during feeding hours. The defensive, escaping from the trough and behavior during handling were noted.

\section{Introduction}

Slugs and snails are of importance to man because of damage they do in agriculture, horticulture and forestry. Among the terrestrial molluscs, slugs seem to be much sensitive to temperature because of their shell less condition. In the dry summer months slugs enter a period of suspended activity, called aestivation. This is only a device to tide over the unfevourable climatic conditions mainly dry weather and fall in temperature.

Raut and Ghose(1984) are of the view that in hibernation/aestivation the body temperature of the snails goes down very much and the rate of metabolism, respiration, heart beat etc. became slow, whereas aestivation is mainly because of the lowering down of atmospheric humidity. The hibernating/ aestivating snail is of a great significance as it is this population which is responsible for restocking an infested area after the effects of normal or man made adverse conditions have disappeared. With the onset of monsoon, the inactive snail which have survived and stress and strain of adverse climatic conditions during aestivation, became active again and resume their biological activity. Mead(1961) has reported that although aestivating snails are often found under very superficial protective conditions. The studies on behavior of the pest slug Semperula maculata during the 
aestivation and refeeding are very scanty.

\section{Materials and Methods}

The collected slugs were brought to the laboratory. Three wide plastic throughs with moist soil having depth of about 5 to 6 inches were taken. A lot of 50 slugs was placed in each trough and they were covered with netlon cloth. The slugs of all the trough were acclimatized at laboratory conditions for a week. They were provided with proper food, sufficient water and ventilation. After acclimatization the slugs from one of the three throughs were placed for aestivation. The slugs in other two throughs were continued to feed and water. As soon as the slugs in aestivation through started to aestivate, they lose weight due to excess dehydration. Thus the slugs were induced for aestivation under laboratory conditions. Few slugs were taken at a time after one to five week from aestivation control through.

\section{Reffeding Method}

Slugs from second through were utilized for refeeding experiment and were fed for 5 weeks.During refeeding they were provided with water, food and sufficient ventilation.

\section{Results and Discussion}

The aestivations in slugs has induced many changes at the organism level.

\section{Normal Behavior}

In the habitat the slugs were found in mass lying one upon another under debris, stones and soft soil layers. They were in groups of 2 to 10 . Some were isolated. When disturbed they started to crawl and tried to escape. When these slugs were brought to laboratory and placed in wide plastic through and were provided with leaves of vegetables and water, some fed on leaves, some tried to escape from the through and some immediately buried into the soil. During acclimatization period for about a week they showed various types of behavior. Some were hidden below the leaves, some were buried in the soil with the help of anterior end. Many of them climbed up on the sides of the through to escape from them. At night they were coming out in search of food, to drink water and fed on the leaves. After sufficient feeding they ignored the food and buried into the soil.

\section{Behaviour During Aestivation}

In the first 3 to 4 days the slugs showed behavior like control slugs. Since during the aestivation water and fed supply was completely stopped. They buried in the soil and come out only during the night time in search of food. Majority of them tried to escape. Some had stretched their bodies and had entangled into netlon cloth below the margin of through where there was dark. In the morning they were again placed in the through. They crawed for a long time in search of food. Their search path was visible by the salivery slime trails.

Their movements after 4 days were slowed down. Most of the times they remain buried into the soil. Only few slugs came out on $5^{\text {th }}$, $6^{\text {th }}$ and $7^{\text {th }}$ day of aestivation. Their body size was very much reduced. Some of the slugs $(4 \%)$ died either in buried state or during crawling on the soil surface. Those died in the soil could be identified by the presence of fruit flies in that part of soil and by bad smell. The buried slugs had kept small aperture and tunnel like opening for the ventilation in the soil. These slugs have died to desiccation or to change in surrounding temperature. The remaining slugs were aestivated which did not come our of soil.Few of these aestivated slugs 
were buried by exposing their anterior end and remaining few were buried deep into the soil. At the time of experiments the slugs were removed carefully by scooping the soil from one end of the through without disturbing other aestivating slugs. To maintain temperature and humidity the through were placed in dark and cold place. The water was poured drop by drop slowly on the soil surface and was allowed to penetrate to the bottom. It kept the soil moist. The aestivated slugs were removed after every week from $1^{\text {st }}$ week of aestivation period and the behavior of these slugs were noted carefully. The behavior and changes in it during aestivation period. After first week of aestivation it has been observed that the slugs showed fast movements and easily escaped from the through when removed from the soil and tried to hide. They avoided light. After second week of aestivation, slugs frequently came out during night time. They crawled out very slowly. The bodies become pale. The amount of mucus secreted by them was less as compared to the first week aestivated slugs. The movements of these slugs were very slow, strained and were very reluctant for movements after $3^{\text {rd }}$ week of aestivation. After $4^{\text {th }}$ week of aestivation the slugs showed dormancy and moved very slowly. They showed very little response to touch. They secreted very small amount of mucus and dirty greenish brownish colored faces. The skin of these slugs was very thin and rough. When these slugs taken out of the soil after $5^{\text {th }}$ week of aestivation, they showed very slow movements. They gave very little response to touch. Their body became narrow, somewhat rounded instead of dorsoventrally flattened. They excreted faces very frequently. During crawling they secreted very less amount of slime.

\section{References}

Mead,A.R.1961:The giant African snail:A problem in economic malacology. The University of Chicago Press,Chicago,USA, 257.

Raut S.K. and Ghose K.C.1984:Pestiferous land snails of India.ZSI Tech.Mong.N 11.151 .

\section{How to cite this article:}

Bharamal, D.L., 2016. Studies on behavior of land slug Semperula maculata during aestivation. Int.J.Curr.Microbiol.App.Sci. 5(1): 390-392. hittp://dx.doi.org/10.20546/ijcmas.2016.501.036 